\title{
The Impact of Using Oraiapp.com on Improving Students' Speaking Skill for Non Native Speaker
}

\author{
Ervina C. M. Simatupang*, Hendar, Ida Zuraida Supri \\ Department of English, Widyatama University, Indonesia
}

Copyright $\mathrm{C} 2019$ by authors, all rights reserved. Authors agree that this article remains permanently open access under the terms of the Creative Commons Attribution License 4.0 International License

\begin{abstract}
The mass use of internet technology in school environment requires the innovative ways in teaching process. The new process of teaching can be created based on the need and the facilities available. Nowadays teachers and students are facilitated by internet connection which can be accessed anywhere and anytime. They can access any information and install any application on the internet. The ease of internet access helps us find a way to support our teaching process more efficient and effective. One application that can improve students' speaking skill is oraiapp.com, this application facilitates teacher in teaching process, especially teaching speaking skill. Not only teacher but also students get benefit from this application. This research aims to describe the teaching process using oraiapp.com, and to identify the improvement of students' speaking skill after using this application. The data analysed are taken from non-native English learners majoring English Language at Widyatama University. The results are those students speaking skill have significant improvement, particularly in their pronunciation, fluency, vocabulary, and they become more confident in presentational speaking and interpersonal speaking.
\end{abstract}

Keywords Oraiapp.com, Teaching Process, Speaking Skill

\section{Introduction}

In the 21 st century, the rapid development of technology influences lifestyles that are increasingly striking. Due to technological developments affected mass communication models to carry out daily living activities. The internet is considered as a complicated tool for ordinary people, but now we can see for yourself what the facts are. The internet has become a common thing for many people and maybe we are among those who have almost all accounts on social networks, interacting intensive with other individuals virtually because in the digital era now mobile phones have become a necessity. Computers or cellphones without internet are considered old or not functioning.

Positive impact Technology development is able to make it easier for us to find the information we need. Surely as a teacher and dose instructor at this time it really needs technology because it can access English learning materials that can be accessed by students wherever they are. Even the features are diverse and can also do quiz online and students are very interested in learning with technology. One of the successes of learning is that students become centers of learning no longer a lecturer as a focus or learning center but students will make them think more and find solutions in learning. The benefits of the student learner's center on Widyatama students are:

1. Make the learning process effective

With learner-centered learning, they will be responsible for themselves in achieving their learning goals. They will be faster in accepting and understanding something proactively in learning.

2. Strengthening students' memory power

When students are required to be active in the learning process, in the sense that they are no longer just focused on the teacher, they will be more powerful in their memory since they get knowledge directly to be practiced, in the sense of not just listening from one source.

\section{Eroding the boredom of students}

Boredom will arise when students are not considered to be in the classroom. They are only used as objects of loyal listeners from teacher's lectures. As a result students will feel bored and will also influence their desire to continue actively in exploring science.

4. Giving confidence to those who have academic deficiencies

SCL gives anyone the opportunity to be proactive in the teaching and learning process. There is no pressure that can decide that this opinion is correct and that opinion is wrong. Because those involved in the discussion themselves are all students. So those who have rarely participated in teaching and learning activities will feel more confident in following them. 


\section{Methodology}

The method applied in this research is qualitative method, in which the research based on descriptive data. The collected data are analysed in accordance with theories chosen, and described based on how to learn English using technology points of views.

The method used in this study is descriptive comparative. Following is the explanation of the method, as Djajasudarma (1993: 7-8) explained: 'descriptive study is a method which aimed to describe, to reveal the idea or the picture systematically, factually and accurately of the data, characteristics and connected phenomena studied. The comparative method is comparing every literature to explore the original literature'. This study is carried out because there is a phenomenon of the significant influence on the use of technology on improving English language skills for the students and lecturer.

\section{Research Questions}

The researcher formulates the following problems:

1. What is the significant influence on the use of technology on improving English language skills for the students and lecturers?

2. What kinds of the skills they get from Orai application?

\section{Purposes of the Research}

1. To find out whether there is a significant influence on the use of Orai app.com towards students and lecturers?

2. To find out what the skills they get from the Orai application

The learning process is centered on students or students, so students have the opportunity and facilities to be able to build their own knowledge so that they will gain a deep understanding that can ultimately improve the quality of students. Through the application of student-centered learning, students are expected to be able to participate actively, always challenged to have critical power, able to analyze and can solve their own problems.

One of the characteristics of the life of modern society is the rapid development of science and technology, which requires everyone to be careful and responsive in interpreting every information received, both from their own country and from other countries (Mackey:2000). With the amount of information coming in from other countries and most of the information using foreign languages, modern society is aware of the need to master foreign languages. Mastery of a foreign language is very important and needs to be improved to help facilitate communication with the community from other countries. As stated in the GBHN in 1993 that the ability to master a foreign language needs to be improved and developed to facilitate communication with other nations in all aspects of life, especially the absorption of information on science and technology while expanding the nation's perspective in line with development needs. To obtain information about science and technology is not only through reading but also in verbal communication activities. By having foreign language skills, especially English, especially English as the language of international communication, it will be easier to obtain clearer information (Alfawair and Al Tobi, 2017; Mayan and Nor, 2017; Yulisutiany, 2018; Ha and Tran, 2018; Garaeva and Ahmetzyanov, 2018; Altunkaya and Ates, 2018; Allam, 2018; Andriansyah et al., 2018; Manzuma-Ndaaba et al., 2018; Bagherpour \& Shamshiri, 2018; Tayebi et al., 2019).

Today the teaching of English is aimed more at oral abilities. Students are not only trained to read and understand texts, but are trained to actively use language and express themselves verbally. Students are also required to be able to master speaking skills in English or other foreign languages, because essentially learning language is learning to communicate with the language learned both orally and in writing (GBPP, 1993: 2). One of the principles of foreign language teaching is the development of active oral language skills together with the development of active oral abilities accompanied by the development of reading and writing abilities. Therefore, in teaching and learning activities in English, teachers are required to be able to develop learning material that is appropriate to the situation and needs needed by students in the future. The development of material for learning speaking skills needs to be emphasized, considering speaking skills are speaking skills are the most difficult skills to master compared to other language skills such as listening, reading and writing skills (Ahmed, Umrani, Qureshi \& Sarmad, 2018; Ali \& Haseeb, 2019; Haseeb, Abidin, Hye, \& Hartani, 2018; Haseeb., 2019; Suryanto, Haseeb, \& Hartani, 2018).

Understanding student centered learning (SCL) is a learning process that is centered on students (learner centered) is expected to encourage students to be actively involved in building knowledge, attitudes and behavior (Labov, 2006; Tolulope, 2017; Rahman and Zhang, 2017;). Through a learning process that actively engages students, means the teacher no longer takes the rights of a learner to learn. Student activities are important because emphasizing learning is essentially an active process in which students use their minds to build understanding (constructivism approach).

English is as one of the foreign languages in Indonesia turned out to get a good place compared to other foreign languages. This can be seen from the fact that English is included as one of the subjects that must be taken by 
Management students at Widyatama University. English courses in junior high schools function as tools for self-development of students in the fields of science, technology and arts and culture. English needs to be mastered by students especially in the ability to

\section{Result and Discussion}

The use of Orai technology is very useful for public speaking to hone in speaking English. The tool is used by students to be accessed freely and can be used anywhere. The use of the Orai tool is very good to use, one of which is to make students practice speaking English and they will be able to evaluate directly after using orai. The use of this tool is very good to be used for Reading and speaking courses in English. Then the second media is through the site www.breakingnewsenglish.com. This media is very good to use for learning reading and academic writing. Students can easily access the link; there are several learning materials available. The media that will be used must pay attention to several provisions with the consideration that the use of the media must be truly effective and effective to improve and clarify student understanding. The use of media in learning is not easy. In using the media must pay attention to several techniques so that the media used can be utilized optimally and not deviate from the purpose of the media. Success in the teaching and learning process also depends on the learning media and adequate infrastructure. In this case, it is clear that the use of media in learning is quite optimal in the field of education which should be mastered by every educator and teacher in modern times like now. This method has been done in my class and it works. Understanding and obtaining student scores are getting better. Not only is that, but the enthusiasm of students for learning English increasing, as seen from the increasing student grades.

The following data of students used the ORAI application. They talked and recorded after that the text would appear while listening to the recording. The assessment is also available. communicate both orally and in writing. This is because English is an international language and is considered important for the purpose of absorption and development of science, technology and arts and culture as well as fostering relations with other nations.

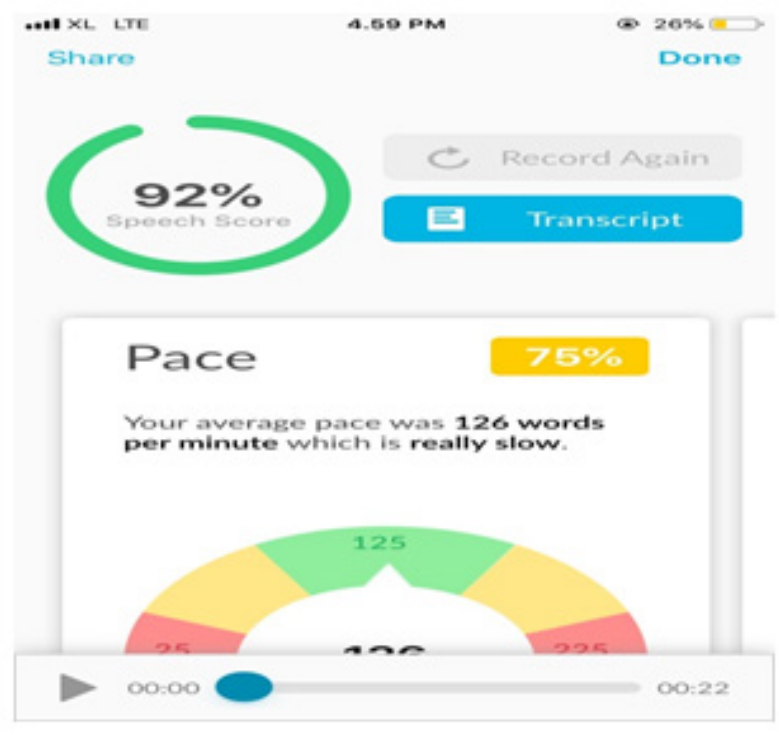

Picture 1. The result of recording

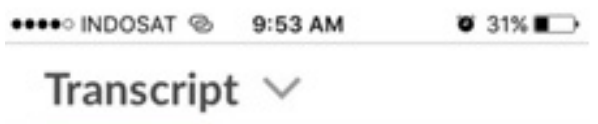

FILLERS PACE ENERGY

Hello, my name is days of autumn around this arena. People usually call me des. I was born in karawang on 2nd february 1998. I am now 20 years old. I' $\mathrm{M}$ a collider at video tomorrow university and $i$ take english as my major. The reason i take english as my major is, because i wish i could be a translator or interpreter. I hope i could achieve my dream and as a college student, $\mathrm{i}$ hope $i$ can do well in my in every subject and get a good grade.

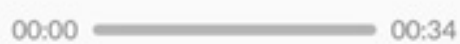

Picture 2. The result of transcript 


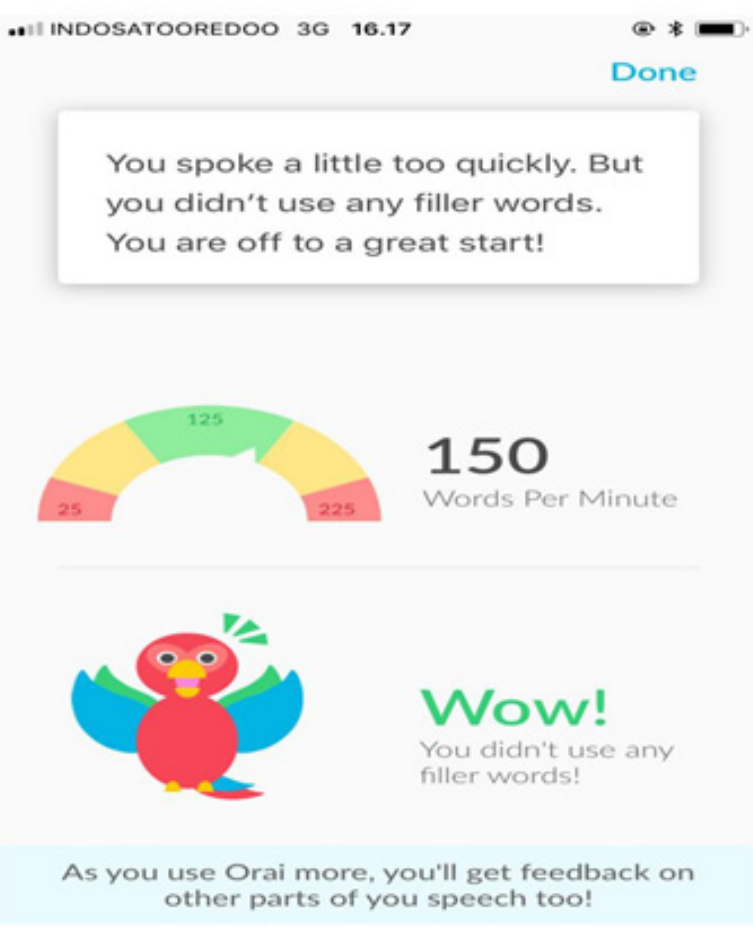

Picture 3. Use of ORAI in lectures in class

Transcript
FILLERS
Hi everyone, how are you today? Let me
introduce myself. My name is angela. You
can call me angel. I am 23 years old. My
hobbies are reading watching movie
playing games and dancing. My parents
love me very much. They give me a lot of
things, especially for my birthday. Well, my
favorite subject is i love reading very much,
since reading is very enjoyable. I have two
sisters and two brothers. They are living in
kalimantan, indonesia, and we are happy
family, since my parents always teach us
how to respect others. Thank you very
much have a nice day. Bye.

$00: 00$ $01: 28$

Picture 4. The result of transcript
The results of using ORAI were seen to help students speak English, be confident and dare to speak in front of people. This application is very transparent, the results of recording can be directly seen on the screen and also there is the recording without us having to click it. Then we can share. Value already exists in the application and also the assessor. However, the teacher no longer needs to judge because there is already a result. Students can see the results of the recording directly.

Therefore, through research, I hope that more people can use this app because it is very helpful for students for public speaking, interviews or for presentation exercises. The result of this research after students get to know this application they are very interested and try to record their voices and always practice so that the results of their final grades are increasing. Even through this application students have begun to be interested in getting to know and associate with technology.

\section{Conclusions}

Learner-centered learning, they will be responsible for themselves in achieving their learning goals. They will be faster in accepting and understanding something proactively in learning. Using Orai Strengthening students' memory power and also improve their speaking. Boredom will arise when students are not considered to be in the classroom. They are only used as objects of loyal listeners from teacher's lectures. As a result students will feel bored and will also influence their desire to continue actively in exploring science. Giving confidence to those who have academic deficiencies.

SCL gives anyone the opportunity to be proactive in the teaching and learning process. There is no pressure that can decide that this opinion is correct and that opinion is wrong. Because those involved in the discussion themselves are all students. So those who have rarely participated in teaching and learning activities will feel more confident in following them.

\section{Acknowledgements}

Thank You Foundation of Widyatama, Widyatama University and Prof. Dr. Mohd Haizam bin Mohd Saudi

\section{REFERENCES}

[1] Alfawair, A. M., \& Al Tobi, A. S. (2017). Counseling Needs for Students with Special Needs at the University. American Journal of Education and Learning, 2(1), 65-74.

[2] Altunkaya, H., \& Ates, A. (2018). Sources of Reading Anxiety among the Learners of Turkish as a Foreign 
Language. Asian Journal of Education and Training, 4(3), 161-169.

[3] Djajasudarma, T. Fatimah.2003. Analisis Bahasa Sintaksis dan Semantis. Jatinangor: Uvula Press Fakultas Sastra.

[4] Frank, Marcella. 1993. Modern English A Practical Reference Guide. New York: Prentice-Hall, Inc.

[5] Garaeva, A. K., \& Ahmetzyanov, I. G. (2018). Awareness of Historical Background as One of the Factors of Better Language Acquisition. International Journal of English Language and Literature Studies, 7(1), 15-21.

[6] Ha, T. P. T., \& Tran, M. D. (2018). Review of Impacts of Leadership Competence of Project Managers on Construction Project Success. International Journal of Emerging Trends in Social Sciences, 4(1), 15-25.

[7] Hartanto, S. John. 1986. Accurate Brief \& Clear English Grammar. Surabaya: Indah.

[8] Hornby, A.S. 1975.Guide to Patterns and Usage in English Grammar. London:

[9] Leech, Geoffrey. 1990. An A-Z of English Grammar and Usage. London: A Division of Hodder and Stoughton.

[10] Lyons, John. 1971. Introduction to Theoretical Linguistics. Cambrige: At The University Press.

[11] Mackey, A., Gass (2000). Studies in Second Language Acquisition, Cambridge University.

[12] Mayan, S. N. A., \& Nor, R. M. (2017). Prospects and challenges of ecotourism sector and poverty eradication in Sabah: The case of orangutans and Mabul Island. Global Journal of Social Sciences Studies, 3(1), 1-12.

[13] Palmer, F.R.1987. The English Verb. New York: longman

[14] Quirk, Randolph et al. 1989. A Grammar of Contemporary English. London: Longman group.

[15] Rahman, K. A., \& Zhang, D. (2017). Material Culture and Environmental Woes: Devotion to Fast Fashion. Humanities and Social Sciences Letters, 5(3), 54-63.

[16] Simpson, J. (2002). Computer- mediated Communication. ELT Journal.

[17] Tolulope, A. (2017). Demographic Variables as Factors Influencing Accessibility and Utilisation of Library Software by Undergraduates in Two Private Universities in Nigeria. Journal of Education and e-Learning Research, 4(3), 92-99.

[18] Yulisutiany, I. (2018). Study of Education Competency and Effect on Learning Process of BCCT Method on Educational Group of Education Age (PAUD) in Sukasari Bandung. International Journal of Educational Technology and Learning, 3(2), 69-77.

[19] Allam, Z. (2018). Students' perception of quality in higher education: An empirical investigation. Management Science Letters, 8(5), 437-444.

[20] Andriansyah, A., Taufiqurokhman, T., \& Wekke, I. (2019). Responsiveness of public policy and its impact on education management: An empirical assessment from Indonesia. Management Science Letters, 9(3), 413-424.
[21] Manzuma-Ndaaba, N., Harada, Y., Nordin, N., Abdullateef, A., \& Rahim, A. (2018). Application of social exchange theory on relationship marketing dynamism from higher education service destination loyalty perspective. Management Science Letters, 8(10), 1077-1096.

[22] Bagherpour, M., \& Shamshiri, B. (2018). The effect of educational methods on creativity of pre-school children: A case study. Management Science Letters, 8(6), 717-724.

[23] Tayebi, S., Manesh, S., Khalili, M \& Sadi-Nezhad, S. (2019). The role of information systems in communication through social media.International Journal of Data and Network Science, 3(3), 245-268.

[24] Ahmed, U., Umrani, W. A., Qureshi, M. A., \& Samad, A. (2018). Examining the links between teachers support, academic efficacy, academic resilience, and student engagement in Bahrain. INTERNATIONAL JOURNAL OF ADVANCED AND APPLIED SCIENCES, 5(9), 39-46.

[25] Ali, A., \& Haseeb, M. (2019). Radio frequency identification (RFID) technology as a strategic tool towards higher performance of supply chain operations in textile and apparel industry of Malaysia. Uncertain Supply Chain Management, 7(2), 215-226.

[26] Haseeb, M., Abidin, I. S. Z., Hye, Q. M. A., \& Hartani, N. H. (2018). The Impact of Renewable Energy on Economic Well-Being of Malaysia: Fresh Evidence from Auto Regressive Distributed Lag Bound Testing Approach. International Journal of Energy Economics and Policy, 9(1), 269-275.

[27] Suryanto, T., Haseeb, M., \& Hartani, N. H. (2018). The Correlates of Developing Green Supply Chain Management Practices: Firms Level Analysis in Malaysia. International Journal of Supply Chain Management, 7(5), 316. 